\title{
ANALISIS PENERAPAN SISTEM INFORMASI MANAJEMEN DAERAH (SIMDA) KEUANGAN PADA BADAN KEUANGAN DAN ASET DAERAH KABUPATEN MALUKU TENGGARA
}

\author{
Trivena Anastasia Rahantoknam ${ }^{1}$, Jantje J. Tinangon ${ }^{2}$, Lidya M. Mawikere ${ }^{3}$ \\ 1,2,3 Jurusan Akuntansi, Fakultas Ekonomi dan Bisnis, Universitas Sam Ratulangi, Jl. Kampus Bahu, Manado, \\ 95115, Indonesia \\ E-mail : trivenaanastasia@gmail.com
}

\begin{abstract}
Financial SIMDA is an application program that is shown to assist Local Government in the area of financial management. The purpose of the implementation of financial SIMDA is to produce financial statements and financial information in a timely, complete, accurate, and reliable manner in accordance with the prevailing provisions and encourage the realization of Good Governance and the implementation of regional financial management based on information technology. The purpose of this research is to analyze the implementation of Financial SIMDA in BKAD of Southeast Maluku Regency. The research method used is descriptive qualitative. The results of the research indicate that in general the staff of BKAD of Southeast Maluku Regency have understood the meaning of financial SIMDA. Factors that have to support implementation of SIMDA financial implementation that is communication, attitude / disposition and bureaucracy structure. Meanwhile, the inhibiting factor is human resources. The quality of information generated by financial SIMDA can be understood, relevant, reliable, and comparable.
\end{abstract}

Keywords : Financial SIMDA,Impplementation SIMDA

\section{PENDAHULUAN}

Indonesia adalah negara yang tergolong berkembang yang memiliki tiga sektor penting dalam perekonomian, yaitu sektor publik, swasta, dan koperasi. Perkembangan pada sektor publik tidak bisa dilepaskan dari peran pemerintah, dimana pemerintah merupakan entitas sektor publik yang paling besar dan dominan. Halim (2008:251) yang dimaksud sektor publik adalah pemerintah dan unit-unit organisasinya, yaitu unit-unit yang dikelola pemerintah dan berkaitan dengan hajat hidup orang banyak atau pelayanan masyarakat, seperti kesehatan, pendidikan, dan bidang sumber daya.

Sejak diberlakukannya otonomi daerah di Indonesia, pemerintah daerah diberi kewenangan oleh pemerintah pusat untuk mengatur pemerintahannya sendiri. Otonomi daerah mulai diberlakukan di Indonesia berdasarkan Undang-Undang Nomor 22 Tahun 1999 tentang Pemerintahan Daerah. Pada tahun 2004, UndangUndang Nomor 22 Tahun 1999 telah dianggap tidak sesuai lagi dengan perkembangan keadaan, ketatanegaraan, serta tuntutan penyelenggaraan otonomi daerah. Oleh karena itu maka Undang-Undang Nomor 22 Tahun 1999 digantikan dengan Undang-Undang Nomor 32 Tahun 2004 tentang Pemerintahan Daerah. Undang-Undang Nomor 32 Tahun 2004 tentang Pemerintahan Daerah telah mengalami banyak perubahan. Salah satunya yaitu Undang-Undang Nomor 12 Tahun 2008 tentang Perubahan Kedua atas Undang-Undang Nomor 32 Tahun 2004 tentang Pemerintahan Daerah. Kemudian mengalami perubahan lagi dan menjadi UndangUndang Nomor 23 Tahun 2014 tentang pemerintahan daerah. Pengertian otonomi daerah menurut UU No 23 Tahun 2014 adalah hak, wewenang, dan kewajiban daerah otonom untuk mengatur dan mengurus sendiri urusan Pemerintahan dan kepentingan masyarakat setempat dalam sistem Negara Kesatuan Republik Indonesia. 
Berdasarkan PP No. 56 Tahun 2005 tentang Sistem Informasi Keuangan Daerah, pemerintah daerah berkewajiban mengembangkan dan memanfaatkan kemajuan teknologi informasi untuk meningkatkan kemampuan mengelola keuangan daerah, dan menyalurkan informasi keuangan daerah kepada publik. Salah satu bentuk pemanfaatan teknologi informasi adalah dengan penggunaan perangkat lunak sebagai alat bantu dalam sistem akuntansi dan keuangan daerah.

Badan Pengawasan Keuangan dan Pembangunan (BPKP) selaku internal auditor dan Pembina Sistem Pengendalian Intern Pemerintah (SPIP) menjawab tuntutan tersebut di atas sekaligus memfasilitasi Pemda dengan merancang suatu sistem informasi terintegrasi yang disebut Sistem Informasi Manajemen Daerah (SIMDA) Keuangan. Walaupun secara umum banyak manfaat yang ditawarkan oleh penerapan SIMDA Keuangan antara lain kecepatan pemrosesan transaksi dan penyiapan laporan, keakuratan perhitungan, penyimpanan data dalam jumlah besar, biaya pemrosesan yang lebih rendah, namun penerapan SIMDA Keuangan pada BKAD Kabupaten Maluku Tenggara masih terhambat oleh sumber daya manusia. Masih terdapat Sumber Daya Manusia yang tidak paham dalam penerapan SIMDA Keuangan. Berdasarkan latar belakang masalah, maka rumusan masalah dalam penelitian ini adalah bagaimana penerapan Sistem Informasi Manajemen Daerah (SIMDA) Keuangan pada Badan Keuangan dan Aset Daerah Kabupaten Maluku Tenggara? Dimana tujuan penelitian ini adalah untuk menganalisis penerapan Sistem Informasi Manajemen Daerah (SIMDA) Keuangan pada Badan Keuangan dan Aset Daerah Kabupaten Maluku Tenggara.

\section{TINJAUAN PUSTAKA}

2.1. Akuntansi

PP No.71 Tahun 2010 menyatakan bahwa Akuntansi adalah proses identifikasi, pencatatan, pengukuran, pengklasifikasian, pengikhtisaran transaksi dan kejadian keuangan, penyajian laporan, serta penginterpretasian atas hasilnya.

Akuntansi bisa didefinisikan sebagai seni, ilmu, sistem informasi yang didalamnya menyangkut pencatatan, pengklasifikasian, dan pengikhtisaran dengan cara sepatutnya dan dalam satuan uang atas transaksi dan kejadian yang setidaktidaknya sebagian mempunyai sifat keuangan serta adanya penginterpretasian hasil pencatatan dan disajikan dalam laporan keuangan (Taswan, 2015:5).

\subsection{Akuntansi Pemerintahan}

Menurut Deddi, $d k k$ (2012:4) akuntansi pemerintahan mengkhususkan dalam pencatatan dan pelaporan transaksi yang terjadi di badan pemerintah. Akuntan pemerintah menyediakan laporan akuntansi tentang aspek kepengurusan dari administrasi keuangan negara.

\subsection{Sistem Informasi Manajemen}

Menurut Rochaety, dkk. (2012:10) "sistem informasi manajemen merupakan perpaduan antara Sumber Daya Manusia dan aplikasi teknologi informasi untuk memilih, menyimpan, mengolah, dan mengambil kembali data dalam rangka mendukung proses pengambilan keputusan sebuah perusahaan".

\subsection{Sistem Informasi Manajemen Daerah (SIMDA)}

Menurut Darea (2015), SIMDA merupakan salah satu upaya dalam rangka memenuhi kebutuhan informasi secara cepat, tepat, lengkap, akurat, dan terpadu, 
untuk menunjang proses administrasi Pemerintahan, pelayanan masyarakat, dan memfasilitasi partisipasi dan dialog publik dalam perumusan kebijakan.

\subsection{Sistem Informasi Manajemen Daerah (SIMDA) Keuangan}

Program aplikasi komputer SIMDA keuangan adalah suatu program aplikasi yang ditujukan untuk membantu pemerintah daerah dalam pengelolaan keuangan daerahnya. Dengan aplikasi ini, pemda dapat melaksanakan pengelolaan keuangan daerah secara terintegrasi, dimulai dari penganggaran, penatausahaan hingga akuntansi dan pelaporannya. (Mitami, 2013)

\subsubsection{Fungsi Program Aplikasi SIMDA Keuangan}

Fungsi utama pengimplementasian SIMDA Keuangan (BPKP, 2008) adalah :

1. Membantu pemerintah daerah dalam melaksanakan pengelolaan keuangan daerah (penganggaran, pelaksanaan, pertanggungjawaban);

2. Menyusun laporan keuangan lebih efisien dan akurat;

3. Menyimpan data keuangan untuk keperluan manajemen lainnya;

4. Menyajikan informasi yang akurat secara efektif dan efisien yang akan digunakan oleh pengguna laporan; dan

5. Mempermudah proses audit bagi Auditor dengan merubah tata cara audit manual menjadi Electronic Data Processing (EDP) audit.

\subsection{Teori Implementasi Kebijakan}

Implementasi kebijakan adalah "suatu proses dinamika yang mana meliputi interaksi banyak faktor"(Grizzle dan Pettijohn: 2002). Pendekatan yang digunakan dalam menganalisis implementasi SIMDA Keuangan mengacu pada teori yang dikemukakan oleh George C.Edward III. Menurut Edward dalam Subarsono (2005:90) "implementasi kebijakan dipengaruhi oleh empat variabel yaitu komunikasi (Communications), Sumber daya (resource), Sikap (diposition) dan struktur birokrasi (bureucratic structure)". Keempat variabel tersebut dilaksanakan secara simultan karena antara satu dengan yang lainnya memiliki hubungan yang erat.

\section{METODE PENELITIAN}

\subsection{Jenis dan sumber data}

Jenis data yang digunakan dalam penelitian ini adalah data kualitatif. Data tersebut berupa gambaran mengenai penerapan SIMDA Keuangan pada Badan Keuangan dan Aset Daerah Kabupaten Maluku Tenggara. Dalam penelitian ini, penulis menggunakan data primer berupa data yang diperoleh langsung dari objek penelitian. Sedangkan, data sekunder yang digunakan adalah dari literatur- literatur, buku- buku yang bersangkutan dengan judul penelitian, dan penelitian- penelitian terdahulu.

\subsection{Metode analisis}

Metode yang digunakan untuk menganalisis data dalam pembahasan ini adalah metode deskriptif dengan pendekatan kualitatif. Metode analisis ini digunakan untuk mendeskripsikan penerapan SIMDA Keuangan pada Badan Keuangan dan Aset Daerah Kabupaten Maluku Tenggara dengan menganalisis faktor penghambat dan pendukung penerapan SIMDA Keuangan, dan Kualitas SIMDA Keuangan. Proses analisis ini di dahului dengan pengumpulan serta informasi yang diperoleh dari pihak terkait yaitu Badan Keuangan dan Aset Daerah Kabupaten Maluku Tenggara, selanjutnya mengolah data serta informasi yang telah diperoleh kemudian dari hasil analisis tersebut ditarik kesimpulan yang logis dan memberikan saran atau masukan 
sebagai perbaikan dalam masalah yang ada di Badan Keuangan dan Aset Daerah Kabupaten Maluku Tenggara.

\section{HASIL ANALISIS DAN PEMBAHASAN}

\subsection{Hasil Analisis}

SIMDA Keuangan adalah sebuah aplikasi komputer yang dirancang oleh BPKP untuk mengolah keuangan daerah. SIMDA Keuangan sangat membantu pemerintah daerah dalam mengolah keuangan daerah, mulai dari penganggaran sampai dengan pelaporan. Selain mempercepat penyajian laporan keuangan, SIMDA Keuangan mempermudah ekspor import data antar SKPD dengan menggunakan flashdisk dan juga mengurangi resiko tingkat kesalahan perhitungan anggaran.. Mereka hanya menginput data ke dalam sistem dan mengawasi proses pengolahannya. Proses pengelolaan laporan keuangan dengan menggunakan SIMDA Keuangan diproses secara otomatis dengan adanya realisasi anggaran. Namun ada beberapa hal tertentu yang perlu dibuat melalui jurnal penyesuaian, misalnya pengakuan utang dan piutang persediaan. Beberapa kendala yang dihadapi dalam penginputan yaitu jika ada belanja atau aset yang mempunyai nomor rekening yang baru. Biasanya jika belum di sinkronkan maka tidak akan terbaca dalam laporan. Tetapi hal tersebut sudah bisa diatasi karena setiap akhir tahun pemegang Admin SIMDA diperintahkan untuk memeriksa dengan teliti setiap rekening. Berikut hasil penelitian mengenai analisis penerapan SIMDA Keuangan .

A. Faktor Penghambat dan Pendukung Penerapan SIMDA Keuangan

Faktor penghambat yang ditemukan dalam hal ini adalah SDM. Hal tersebut diungkapkan oleh KSB. Akuntansi "saya rasa SDM di kantor ini belum memadai terkait dengan proses pengoperasian SIMDA Keuangan pada BKAD Kab. Maluku Tenggara secara kualitas telah mengerti tentang tujuan dari penerapan SIMDA Keuangan tetapi secara kuantitas masih terdapat Sumber Daya Manusia yang tidak paham dalam penerapan SIMDA Keuangan jadi masih ada ketergantungan terhadap beberapa orang yang memahami SIMDA, kan namanya penerapan suatu sistem semua harus memahami sistem tersebut".

Faktor pendukung dalam penerapan SIMDA Keuangan adalah sebagai berikut :

\section{A. Komunikasi}

Komunikasi dalam bentuk sosialisasi pada BKAD Kabupaten Maluku Tenggara mengenai penerapan SIMDA Keuangan cukup baik. Hasil wawancara dengan beberapa staf menunjukkan bahwa sebelum SIMDA Keuangan diterapkan sudah ada komunikasi baik dari atasan ke bawahan ataupun sesama pegawai bahwa ada kebijakan baru yang akan diterapkan, termasuk aplikasi terbaru maka akan disosialisasikan terlebih dahulu. Komunikasi dalam bentuk sosialisasi pada BKAD Kab. Maluku Tenggara mengenai penerapan SIMDA Keuangan cukup baik.

B. Disposisi atau Sikap

Dalam hal disposisi atau sikap ini, ditemukan adanya respon yang baik dari para implementor karena mereka sadar bahwa penerapan SIMDA Keuangan akan membawa dampak yang baik sehingga mereka setuju untuk menerapkan SIMDA keuangan.

\section{Struktur Birokrasi}

Tingkat pengawasan hierarkis terhadap keputusan sub unit dan proses pelaksanaan penerapan SIMDA Keuangan pada BKAD Kab. Maluku Tenggara sudah cukup baik. Hal tersebut terungkap dalam wawancara dengan KSB. 
Akuntansi Beliau mengatakan bahwa "Disini hanya ada satu admin SIMDA Keuangan, jadi adminlah yang bertugas untuk mengawasi jalannya penerapan sistem itu. Sejauh ini sistem tidak pernah bermasalah".

\section{B. Kualitas Informasi SIMDA Keuangan}

Penerapan SIMDA Keuangan pada BKAD Kab. Maluku Tengara dilihat dari segi kualitas terdiri dari output yang dihasilkan dapat dipahami, relevan, andal, dan dapat diperbandingkan.

\subsection{Pembahasan}

Setelah melakukan penelitian pada Badan Keuangan dan Aset Daerah Kab. Maluku Tenggara, peneliti melihat bahwa secara umum pegawai yang terkait dengan proses pengoperasian SIMDA Keuangan pada BKAD Kab. Maluku Tenggara secara kualitas telah mengerti tentang tujuan dari penerapan SIMDA Keuangan tetapi secara kuantitas masih terdapat Sumber Daya Manusia yang tidak paham dalam penerapan SIMDA Keuangan.

Hasil wawancara dengan beberapa pegawai BKAD Kab. Maluku Tenggara menunjukkan bahwa SIMDA Keuangan memudahkan mereka dalam proses pengolahan data keuangan, dimana pegawai hanya bertugas untuk menginput data dan secara otomatis data tersebut akan terproses. Hal ini membuat proses pelaporan keuangan menjadi lebih mudah dan dapat mengefektifkan waktu penyusunan laporan keuangan. Selain manfaat dan tujuan penerapan SIMDA Keuangan yang telah dipahami, pegawai juga harus memahami setiap input yang akan diolah atau diproses dengan menggunakan SIMDA Keuangan serta output yang akan dihasilkan. Adapun output yang dimaksud adalah elemen-elemen laporan keuangan pemerintah daerah yang diatur dalam PP No. 71 Tahun 2010.

\section{A. Faktor Penghambat dan Pendukung Penerapan SIMDA Keuangan}

Dari hasil penelitian dengan melakukan wawancara dengan beberapa pegawai BKAD Kab. Maluku Tenggara ditemukan bahwa kendala atau faktor penghambat penerapan SIMDA Keuangan pada BKAD Kab. Maluku Tenggara adalah Sumber Daya Manusia. Secara kualitas telah mengerti tentang tujuan dari penerapan SIMDA Keuangan tetapi secara kuantitas masih terdapat Sumber Daya Manusia yang tidak paham dalam penerapan SIMDA Keuangan jadi masih ada ketergantungan pada sebagian orang yang memahami SIMDA Keuangan. Dengan demikian, hal ini tidak sesuai dengan teori implementasi kebijakan menurut Edward III (1980) dimana sumber daya manusia merupakan faktor penentu keberhasilan penerapan.

Faktor pendukung dalam penerapan SIMDA Keuangan adalah sebagai berikut :

A. Komunikasi

Hasil wawancara dengan beberapa staf menunjukkan bahwa sebelum SIMDA

Keuangan diterapkan sudah ada komunikasi baik dari atasan ke bawahan ataupun sesama pegawai bahwa ada kebijakan baru yang akan diterapkan, termasuk aplikasi terbaru maka akan disosialisasikan terlebih dahulu. Hal ini sesuai dengan teori implementasi kebijakan menurut Edward III (1980) dimana komunikasi merupakan faktor penentu keberhasilan penerapan. Berdasarkan analisis tersebut diatas, ditemukan bahwa untuk penerapan SIMDA Keuangan yang optimal pada BKAD Kabupaten Maluku Tenggara didukung oleh adanya komunikasi atau sosialisasi yang aktif baik dari atasan kepada pegawai maupun antar pegawai.

B. Disposisi atau Sikap 
Salah satu faktor yang mempengaruhi efektifitas penerapan kebijakan adalah sikap implementor. Dalam hal disposisi atau sikap ini, ditemukan adanya respon yang baik dari para implementor karena mereka sadar bahwa penerapan SIMDA Keuangan akan membawa dampak yang baik sehingga mereka setuju untuk menerapkan SIMDA keuangan.

C. Struktur Birokrasi

Unsur yang mungkin berpengaruh terhadap suatu organisasi dalam penerapan kebijakan salah satunya adalah tingkat pengawasan hierarkis terhadap keputusan-keputusan sub unit dan proses-proses dalam badan pelaksana (Edward III : 1980). Hasil wawancara menunjukkan bahwa pengaruh struktur birokrasi khususnya dalam kaitannya dengan pengawasan atas penerapan SIMDA Keuangan dapat dilihat dari penyajian laporan keuangan yang tidak pernah terhambat oleh SIMDA Keuangan. Dengan adanya pengawasan yang baik dan perhatian khusus oleh admin SIMDA bentuk kegagalan yang disebabkan oleh sistem dapat diantisipasi, contohnya dengan pengadaan server cadangan. Hal tersebut membuktilan bahwa struktur birokrasi khususnya dalam hal pengawasan juga memegang peranan penting dalam mendukung penerapan SIMDA Keuangan.

\section{B. Kualitas Informasi SIMDA Keuangan}

1. Dapat Dipahami

Kualitas informasi yang dihasilkan SIMDA Keuangan mudah dipahami oleh pengguna laporan keuangan seperti masyarakat, para wakil rakyat, pihak yang memberi atau berperan dalam proses donasi, investasi, dan pinjaman, dan pemerintah. Hal itu terbukti dalam alur pembuatan RKA harus disetujui oleh para wakil rakyat setelah disetujui kemudian membuat DPA dan diterbitkan Peraturan Bupati yang dapat dilihat oleh semua elemen pemerintah dan masyarakat.

2. Relevan

Suatu laporan keuangan dapat dikatakan relevan apabila informasi yang termuat didalamnya memiliki manfaat sesuai dengan tindakan yang akan dilakukan oleh pengguna laporan keuangan. Agar bermanfaat, informasi harus relevan untuk memenuhi kebutuhan pengguna laporan keuangan dalam proses pengambilan keputusan. Seperti hasil wawancara dengan KSB. Akuntansi, setiap transaksi dikelompokan berdasarkan jenisnya masing-masing, dan itu sudah terprogram langsung dalam sistem .

3. Andal

Laporan keuangan yang dihasilkan SIMDA Keuangan dapat dikatakan andal, hal itu bisa dilihat dari :

a. Penyajian jujur setiap transaksi dibuktikan dengan laporan pertanggung jawaban.

b. Dapat diverifikasi yaitu laporan keuangan yang dihasilkan SIMDA Keuangan telah diuji oleh BPK, dan pertanggung jawaban pelaksanaan pendapatan dan belanja.

4. Dapat Diperbandingkan

Laporan keuangan yang dihasilkan SIMDA Keuangan dapat dibandingkan antar periode sebelumnya, dan antar instansi untuk mengidentifikasi posisi dan kinerja keuangan, termasuk pengungkapan kebijakan akuntansi yang digunakan. Dengan demikian laporan keuangan yang 
dihasilkan SIMDA Keuangan telah memenuhi karakteristik dapat diperbandingkan.

\section{KESIMPULAN DAN SARAN \\ 5.1. Kesimpulan}

Berdasarkan hasil penelitian dan pembahasan pada bab sebelumnya, maka dapat diambil kesimpulan sebagai berikut :

1. Penerapan SIMDA Keuangan pada BKAD Kabupaten Maluku Tenggara telah memiliki beberapa faktor pendukung dalam penerapannya yaitu komunikasi aktif yang telah dilakukan oleh semua pihak yang terkait dengan penerapan SIMDA Keuangan, adanya sikap implementor yang menerima/setuju atas pelaksanaan penerapan SIMDA Keuangan serta dukungan dari kepala kantor/pemimpin, dan Struktur birokrasi yang berperan dalam pengawasan atas jalannya sistem aplikasi komputerisasi SIMDA Keuangan tetapi masih terdapat beberapa faktor pendukung yang belum terpenuhi yaitu Sumber Daya Manusia. Secara kualitas pegawai Badan Keuangan dan Aset Daerah Kabupaten Maluku Tenggara telah memahami tujuan dari penerapan SIMDA Keuangan namun secara kuantitas masih terdapat SDM yang tidak paham dalam penerapan SIMDA Keuangan.

2. Kualitas informasi yang dihasilkan SIMDA Keuangan antara lain :

a. Dapat Dipahami

Kualitas informasi yang dihasilkan SIMDA Keuangan mudah dipahami oleh pengguna laporan keuangan seperti masyarakat, para wakil rakyat, pihak yang memberi atau berperan dalam proses donasi, investasi, dan pinjaman, dan pemerintah.

b. Relevan

Laporan keuangan yang dihasilkan SIMDA Keuangan Relevan karena memenuhi syarat-syarat dalam PP No.71 Tahun 2010 yaitu memiliki manfaat umpan balik, memiliki manfaat prediktif, tepat waktu, dan lengkap.

c. Andal

Laporan keuangan yang dihasilkan SIMDA Keuangan Andal karena memenuhi syarat-syarat dalam PP No.71 Tahun 2010 yaitu Penyajian jujur setiap transaksi dibuktikan dengan laporan pertanggung jawaban dan Dapat diverifikasi yaitu laporan keuangan yang dihasilkan SIMDA Keuangan telah diuji oleh BPK,.

d. Dapat Diperbandingkan

Laporan keuangan yang dihasilkan SIMDA Keuangan dapat dibandingkan

\subsection{Saran} antar periode sebelumnya.

Saran yang dapat diajukan dalam penelitian ini adalah meningkatkan kualitas SDM dengan melakukan sosialisasi dan pelatihan khusus penggunaan SIMDA Keuangan bagi yang belum paham. Dalam rangka penerapan SIMDA Keuangan pada instansi lain yang akan menerapkan SIMDA Keuangan sebagai sistem komputerisasi pengolahan data keuangannya perlu memahami maksud dan tujuan dari penerapan SIMDA Keuangan. Hal ini turut meningkatkan efektivitas penerapan SIMDA Keuangan sehingga mampu menghasilkan informasi keuangan yang berkualitas dan dapat disajikan tepat waktu. 


\section{DAFTAR PUSTAKA}

Darea, Devita Wulandari. 2015. Evaluasi penerapan sistem informasi manajemen daerah (SIMDA) Keuangan pada DPPKAD Kabupaten Kepulauan Sangihe. Universitas Sam Ratulangi. Manado. Jurnal EMBA Vol.3. No.2 ISSN:2303-1174 Hal. 144-122

Grizzle dan Pettinjjohn. 2002. Teori Inplementasi Kebijakan, (http://repository.unhas.ac.id/bitstream/handle/123456789/9950/SKRIPSI\%20BARU. pdf). Diakses pada tanggal 20 agustus 2017.

Halim, A., \& Kusufi, S., 2012. Akuntansi Sektor Publik : teori, konsep dan aplikasi. Salemba Empat : Jakarta.

Mitami, Dian. 2013. Analisis Penerapan Informasi Manajemen Daerah Keuangan Pada Pemerintah Daerah Kabupaten Pangkep. E-Journal Unhas. http://repository.unhas.ac.id/handle/123456789/9950. Diakses Juni,2014. Hal. 1-73

Pangestika, Aulia Lorie. 2016. Efektivitas Penerapan Sistem Informasi Manajemen Daerah (SIMDA) Pada Dinas Pendapatan Pengelolaan Keuangan dan Aset Daerah (DPPKAD) Kabupaten Tegal. Politeknik Harapan Bersama. Tegal.

Peraturan Pemerintah Nomor 56 tahun 2005 Tentang Sistem Informasi Keuangan Daerah.

Peraturan Pemerintah Nomor 71 Tahun 2010 Tentang Standar Akuntansi Pemerintahan.

Riyanto., \& Agus, P., 2015. Akuntansi pemerintah daerah berbasis akrual. Cetakan Pertama. Pustaka Pelajar. Yogyakarta.

Rochaety, E., Ridwan, F. \& Setyowati, T., 2013. Sistem informasi manajemen. Edisi Dua. Mitra Wacana Media. Jakarta.

Satgas Pengembangan SIMDA 2008. SIMDA dan Penerapannya. Jakarta: Badan Pemeriksa Keuangan dan Pembangunan.

Sugiyono, 2013. Metode Penelitian Pendidikan (Pendekatan Kuantitatif, Kualitatif, dan $R \& D)$. ALFABETA. Bandung.

Taswan, 2015. Akuntansi Perbankan . Cetakan Keempat. UPP STIM YKPN. Yogyakarta.

Undang-Undang Nomor 23 Tahun 2014 Tentang Pemerintahan Daerah. 